Kindall-Smith, M., McKoy, C. L., \& Mills, S. W. (2011). Challenging exclusionary paradigms in the traditional musical canon: Implications for music education practice. Version of record published in: International Journal of Music Education, 29(4), 374-386.

doi:10.1177/0255761411421075 The official online Sage version of this article can be found at http://ijm.sagepub.com/content/early/2011/09/24/0255761411421075

\title{
Challenging exclusionary paradigms in the traditional musical canon: Implications for music education practice
}

\author{
Marsha Kindall-Smith, Constance L. McKoy, and Susan W. Mills
}

\begin{abstract}
The authors propose that best practices in music education require a conceptual understanding of music teaching and learning based on a perspective of social justice and equitable access for all students. Examinations of the relationship between the tenets of culturally-responsive teaching and three dimensions of music teaching and learning (musical content, instruction, and context) are presented: (1) historically, through the identification of neglected African American contributions to Appalachian music; and (2) pedagogically, through the chronicling of social justice content and culturally-responsive instruction as taught in an urban university and public middle school. The implications of issues of power and social justice for music education are further contextualized within the lens of critical pedagogy to uncover possibilities for a 21st century canon of music teacher preparation that will maximize the potential to transform music education practice.
\end{abstract}

\section{ARTICLE}

The content, historical development and pedagogy comprising present-day music education and music teacher preparation in the United States of America (USA) continues to reflect a predominantly Western European cultural perspective. Consequently, contributions from other cultural traditions often are only peripherally represented in the knowledge base of music education (Green, 2001; Kwami, 2001; Small, 1999; Spruce, 2001). The resulting cultural hegemony inadvertently promotes stereotypes by skimming the surface of global music making and ignoring the ethnic particularities of diverse groups (Johnson,

2004).

Researchers in music and music education have demonstrated conclusively that a wide variety of cultural and ethnic groups have contributed to American musical culture; however many of these cultural 'voices' fail to be represented in the choices music educators make regarding curriculum content. For example, research on the history of Appalachian music included repertoire influenced by African American culture, but did not acknowledge African American membership in Appalachian culture (Hay, 2005; Mills, 2007; Suttles \& Hopkins, 2002). Similarly, current research in music teacher education often overlooks urban students, primarily students of color, as important voices influencing American musical culture by not addressing the challenge of preparing music teachers to understand diversity (Benedict, 
2006; Kindall-Smith \& Mills, 2008; Robinson, 2002). In both cases, significant voices have been omitted from the mainstream of the musical canon.

Solutions to the problem of exclusionary paradigms in music education may be found in instructional approaches rooted in concepts related to social justice. According to Nieto and Bode (2008), social justice is 'a philosophy, an approach, and actions that embody treating all people with fairness, respect, dignity, and generosity' (p. 11). Additionally, they posit that social justice in education functions to challenge cultural misconceptions, untruths, and stereotypes that lead to structural inequality and discrimination based on race, social class, gender, and other social and human differences; provide all students with equitable access to instructional and educational resources; draw on students' talents and strengths to increase learning; and foster a learning environment that promotes critical thinking and supports agency for social change (Nieto \& Bode, 2008).

In calling for reform in teacher education, scholars such as Villegas and Lucas (2002) and Gay (2002) have identified culturally-responsive teaching as one approach for addressing the tenets of social justice in education and in teacher education. Gay (2002) defined culturally-responsive teaching as 'using the cultural characteristics, experiences, and perspectives of ethnically-diverse students as conduits for teaching them more effectively' (p. 107). We propose that the development of best practices in music education across multiple demographic and cultural settings requires a conceptual understanding of music teaching and learning based on a perspective of social justice, equitable access, and culturallyresponsive instruction for all students of music and music education.

Concepts of social justice, equitable access and culturally-responsive pedagogy may best be understood initially if viewed in relationship to a conceptual model developed by Butler, Lind, and McKoy (2007) and designed to illustrate five dimensions of the teaching and learning process in music (teacher, student, content, instruction and context) that, by virtue of being impacted or affected by race, ethnicity, and culture, may serve as barriers to or supports for music learning among diverse student populations (see Figure 1). In that social justice, equitable access, and culturally-responsive pedagogy represent concepts derived from our growing understanding of how race, ethnicity, and culture mediate learning and teaching, and are meant to remove barriers to learning, they are salient to the conceptual model.

As Tuckman (1999) noted, a conceptual model is 'a complex proposal of all the variables and their interconnections that make a particular outcome, such as learning . . . happen' (p. 32). One of the purposes or functions a conceptual model might serve is to map reality; that is, to provide a way to identify components comprising a process or phenomenon and allow for the investigation of potential relationships between and among phenomenological components (Butler et al., 2007).

Although the dimensions of this conceptual model may be considered separately, and the 'teacher' and 'student' represent key dimensions in the model, Butler, Lind, and McKoy observed that 'it is not uncommon for factors from one category to influence or interact with those from one or more of the other categories' (2007, p. 244). For the current discussion, the conceptual model provides a framework within which the phenomenon of missing voices in music education may be examined: (1) historically, including omissions of contributions by a specific cultural group in the traditional music canon; (2) pedagogically, including instructional examples that reflect possibilities for a new, 21st century canon of repertoire and practice in music education and music teacher education; and (3) critically, including explorations of the value of critical theory in transforming the future landscape of music education. 


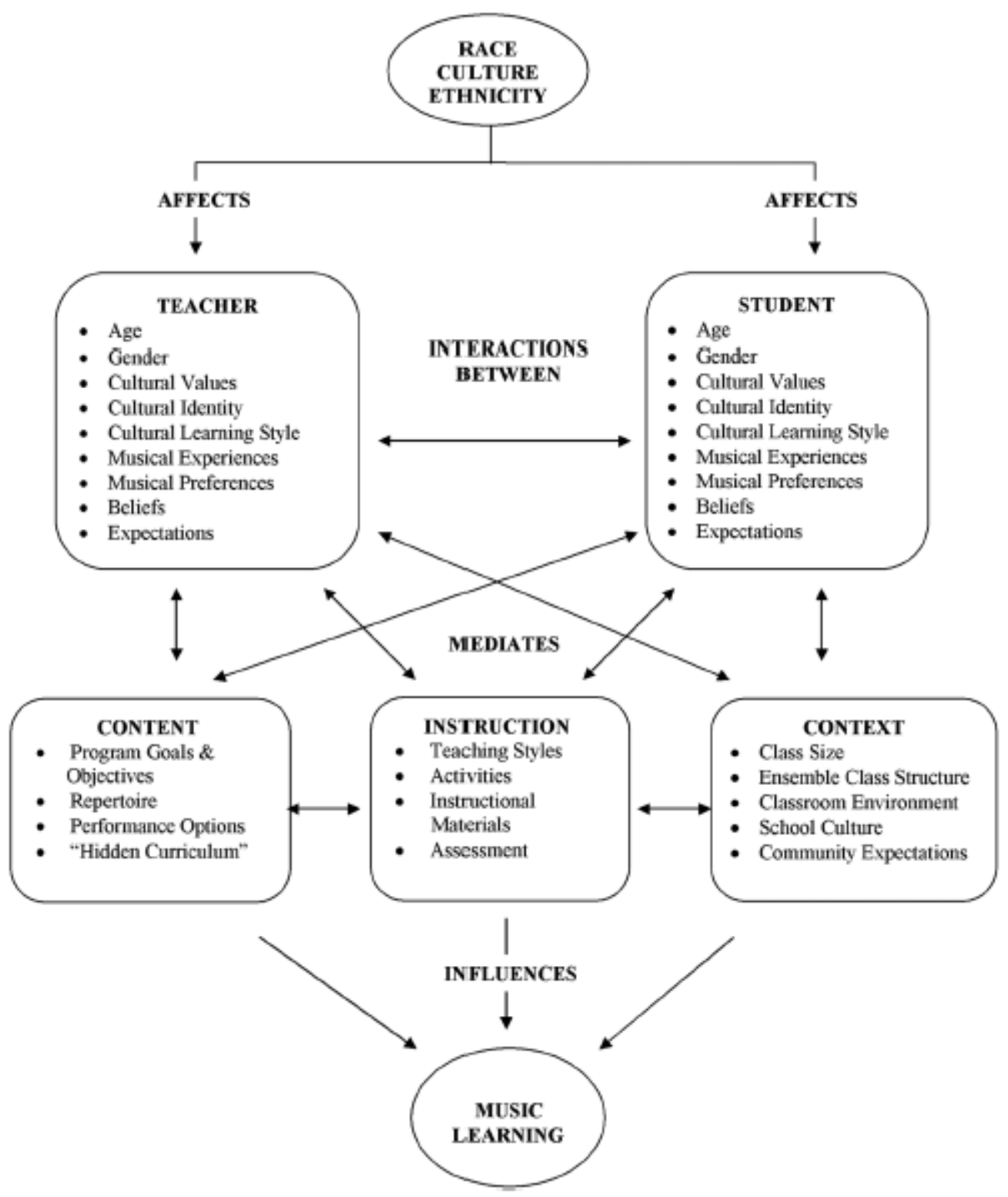

Figure 1. Conceptual model illustrating dimensions of the music learning and teaching process influenced by race, ethnicity, and culture (Butler, Lind, \& McKoy, 2007)

\section{Missing Appalachian voices}

From 1938 to 1973, Professor Leonard W. Roberts collected children's songs and singing games from students at schools and colleges in eastern Kentucky, and from their families, in field recordings. A review of this collection exposed an absence of acknowledged African American games and songs, but musicians should know there are many musical influences by Africans, and African Americans. The song 'Little Bitty Baby,' often titled 'Children Go Where I Send Thee' in current publications, is one example. As with several other songs and games that were listed in Roberts' (2003) collected works, no acknowledgement of African American influence or even participation could be found for this song. 
Nevertheless, a footnote in a song collection by scholar and song collector Jean Ritchie explains that the song was brought to her family by the 'colored' students at a nearby settlement school (Ritchie, 1997).

Twentieth-century settlement schools were created to provide secondary education for mountain youth. The teaching of music, along with preservation of regional folklore, became central to the focus of these schools, possibly the largest clearinghouses for Appalachian folkways. Maintaining and documenting the heritage of the people was especially crucial given the introduction of railroads, coal mining, radios, television and trade that began after the Civil War, and continued to change the political, social and environmental landscape for decades. Song collectors and social workers in the early 20th century defined Appalachia as the mountain region settled by descendants of the British Isles, and later by Germans, with little thought to the descendants from Africa including former slave families, railroad workers, miners, and children. Collections of traditional music such as Roberts' were gathered primarily in legally-segregated White schools in the US; thus, there are voices missing from the repertoire of musical memories. During much of the collection period, Berea College (Academy) was closed to African American students; they were assigned to attend the alternative Lincoln Institute (Wilson, 2006), which does not house such a collection of Appalachian songs and singing games.

Cultural informants, literature, and artifacts have revealed that there were interactions among African American and White people in social lives, working environments and even in some educational settings deep in the mountains, but not in the established institutions of secondary and higher education (Hawes \& Jones, 1972; Hay, 2005; Kindall-Smith \& Mills, 2008; Lomax, 1960; Ritchie, 1997; Suttles \& Hopkins, 2002).

In 1910 the Council of the Southern Mountains was formed and led by self-selected leaders, scholars, and social workers in the Appalachian communities of West Virginia, Kentucky, North Carolina, and Tennessee. Racial inequality and social justice for workers are among the topics of many letters in the council archives (Mills, 2007). As a council member, Roberts was undoubtedly aware of the multicultural nature of the region, but his folklore collection lacks all but derogatory references to African Americans. As the famous creator of the canon of ballads referenced in Roberts' published works and in the majority of similar publications, Francis Child (and other scholars such as Cecil Sharp) contributed the dominant characteristic of an Appalachian person that has persisted in literature and in stereotypes to the present day: as a person of English, Irish or Scottish descent (Hay, 2005). Thus, the Roberts collection potentially reinforces the ideal of a 'pure' or 'real' Appalachian person as specifically Anglo-Appalachian if critical questions are not asked. Four fundamental questions presented here could form the basis for examining the repertoire of the Roberts collection through the lens of critical inquiry.

1. Was there no African or African American influence in Appalachian folk music?

2. Did all African Americans adapt Anglo-American folkways in Appalachia?

3. Was there a political or social force preventing reference and inclusion of African American and other minorities from consideration?

4. Were African American references and repertoire deliberately omitted?

The ethnic makeup of Appalachia has included African Americans as early as it has included wealthy Scots, who arrived in the mountains with their African slaves from the British Isles (Hay, 2005). African Americans were present in the mountains but treated as a distinctly separate culture. This distinction is understandable in the context of legally-segregated educational institutions, but historical inquiry should not so easily dismiss the influence and references of African American children's music. The missing voices of African Americans described in the chronicle of the historic collection of 
Appalachian folk music bring to the forefront considerations of the impact of cultural hegemony on the musical canon of a culture. Those who decide what comprises the canon of knowledge about a culture's music simultaneously decide what is excluded from that canon of knowledge.

The current situation in US urban music classes is reminiscent of the historical phenomena of missing voices in Appalachian music, in that urban students are often segregated, with poor students and students of color losing opportunities, further isolating them and their communities and preventing them from being heard in a democracy. What follows is a discussion of how these inequities have been addressed in one specific music teacher preparation program in which the instructor explored possibilities for social justice through music teacher education pedagogy and practice.

\section{Missing urban voices}

Complexities, contradictions, and crises are characteristics of urban education. For many, the term 'urban' is a signifier for crises including neighborhoods with non-White violence, narcotics, poverty, crumbling houses, failing schools, and absence of family values (Kincheloe, Hayes, Rose, \& Anderson, 2007). The characteristics most salient to this discussion are profound economic disparity, schools and school districts with larger numbers of students, higher rates of ethnic, racial, religious, and linguistic diversity, and school boards factionalized by the challenge of equitable distribution of resources (Kincheloe et al., 2007).

There is a disparity between the cultural backgrounds of many students and those of their teachers (Darling-Hammond, French, \& Garcia-Lopez, 2002; Toppo, 2003). Given that teacher education research has shown that the majority of pre-service teachers are White, female, and middle class, from small towns or suburbs, and with limited diversity experiences and negative attitudes and beliefs about people who differ from themselves, this disparity has a negative impact on teacher expectations (Hollins \& Guzman, 2005). At the Ninth International Conference on Cultural Diversity in Music Education, KindallSmith

stated:

If we avoid teaching pre-service teachers how to confront their prejudices and how to validate the experiences of students of color, then too many of our music education graduates will continue to avoid music teaching positions in urban schools while they hibernate in practice rooms, work in the service sector, and wait for suburban openings. (Kindall-Smith \& Mills, 2008)

Three music teacher educators who contributed to chapters featured in Volume I of Teaching Music in the Urban Classroom (Frierson-Campbell, 2006) described successful urban school music teachers in elementary schools. Robinson (2006) referenced Gay's (2002) components of culturallyresponsive teaching and its application in music education and concluded that it is 'more of an attitude than method in working with students of color' (p. 39). Smith (2006) described the beginning music teachers with whom she has worked as having cultivated a disposition for diversity and desire 'to correct the deficiencies of their own educations' (p. 60). Abril (2006) revealed how veteran music teachers persevered despite the urban complexities identified by Kincheloe et al. (2007). Although Smith and Abril do not specifically identify their respective approaches as being based on culturally-responsive pedagogy, their teachers are becoming and have become culturally responsive in their respective urban settings.

Kindall-Smith's narrative analysis in The National Journal of Urban Education and Practice (2008a) included how students responded to their first semester of instruction with supplementary social justice readings in required music education courses in 2005. According to Kindall-Smith, keeping music education content at the core of each course at all times was crucial; usually, each class began with 30 minutes of music education curriculum, leaving 10 minutes for discussion about supplementary readings. 
Kindall-Smith had previously described the instructional methodology and student responses at the October 2006 International Conference on Social Justice and Equity in Music Education at Columbia University. Two new instructional initiatives in September 2006 were the assignment of cooperative group class presentations to enhance students' understanding about supplementary materials, and the inclusion of articles about rural schools in the course readings.

In an effort to demonstrate some of the activities included in the methods courses and the practical application of social justice content in a public school music education context Kindall-Smith conducted a session entitled Teaching Social Justice IS Touching Lives at the 2008 MENC (The National Association for Music Education) National Biennial In-Service Conference (2008b) with 10 Caucasian preservice music teachers from The University of Wisconsin-Milwaukee (USA). One skit from the Introduction to Music Education course was, 'Reporting Live from an Urban School' and 'Emily,' a student participant, indicated:

... we are Caucasian suburbanites who, inspired by our well-funded, successful programs, have chosen to pursue music education. What we knew of the urban school setting was formed largely by the horror stories heard in the media; [we] had no knowledge of how music education functions in this setting, other than the idea that it is the first program slashed from the budget in the wake of No Child Left Behind . . . This course was the first experience we had where anyone said anything good about the urban music education program, and while acknowledging the challenges, reminded us that students are students anywhere, and they all need music to be a part of their lives.

A skit from the Teaching Elementary General Music course was 'Understanding African Americans.' Student participant 'Sarah' articulated:

Many of the scenarios and topics covered in this presentation come from my real-life experiences. As a third year urban music educator, I have dealt with many African- American students and parents. My initial classroom preparations did not include understanding the variety of behaviors and strategies to deal with them found in other cultures. In Dr. Kindall-Smith's class, I appreciated her taking the time to discuss such matters and relate them to the classroom. Her focus not on just the culture of African-Americans, but on other non-dominant cultural groups has helped prepare all her students to better understand and reach the students and parents of those cultural groups. This prepares and equips us for better teaching methodology, management, and personal relationships, both in and out of the classroom.

During the MENC session Martha Albers, an urban public school music teacher, presented five of her Milwaukee public school students (three African American, one Latina, and one White) in two projects, one of which involved viewing and analyzing the musical West Side Story. In describing the West Side Story project, 'Janice' and 'Richard,' two African American sixth-grade students, mentioned several issues identified by Kincheloe et al. (2007). 'Janice' stated:

Our definition of social justice means that people in our community need to prevent violence and the rights for people should be equal for everyone ... People should not be judged by skin color, and religion, but treated with respect and equal rights... What we learned from West Side Story and talking about social justice is that violence is not the way to solve problems ... We should try to stop the violence by talking it out, walking away from the situation, and ignoring the person who tried to start something . . . My poster says, 'With social justice imagine how much better the world would be' . . . Now people can't ever go anywhere [in my community] because of all the 
violence. This affects my life because my auntie died from someone shooting her for no good reason. America will be so much better if people use social justice.

'Richard' elaborated further:

We discussed the questions our music teacher gave us. Then we discussed the quotes in the movie and what it means to us. This quote was by Maria. She said, 'All of you . . . you all killed him, not with bullets or guns and violence, but with hate.' Once I had so much hatred, I punched someone in the jaw. It felt good, but later I felt bad about it. It didn't solve anything . . . Guns lead to bigger problems. We discussed making posters for our school and neighborhood watches, telling people of all ages, and telling the government that no one should be allowed to have guns . . Violence is not the way to solve problems. That's not social justice.

At the time of the presentation, Albers had been teaching for six years, including five years at Hartford School which has core values of rigorous academic standards, arts integration, and social justice from kindergarten through eighth grade. Regarding the collaboration, Kindall-Smith described Albers as a dynamic cooperating teacher during observations and student teaching placements. Albers' assertion that social justice content engaged middle school students corroborated Nieto and Bode's assertion that students in middle grades are 'very conscious of what is fair and unfair' (2008, p. 53).

Cochran-Smith (2008) encouraged music teacher educators to challenge all aspects of educational inequality:

we need multiple outcomes as well as multiple measures of those outcomes - outcomes such as candidates' practices and judgments, the cognitive complexity of the learning opportunities they provide to students, the degree to which teachers help to produce well-rounded citizens, and how teacher candidates learn to teach effectively for social justice. (pp. 13-14)

Cochran-Smith's statement and research cited previously in this discussion support a mission articulated by Kindall-Smith (2006) that music teacher educators should enable pre-service music students to understand: multicultural music in tandem with the development of positive attitudes and behaviors toward diversity; culturally-relevant/responsive pedagogy; characteristics of successful urban teachers; and social justice for all students in all schools. At the 2008 MENC National Biennial In-Service Conference, pre-service teachers and middle school students presented passionate, creative outcomes of music education taught from social justice perspectives.

\section{Implications of culturally-responsive pedagogy}

As we have demonstrated, it is possible to begin to rectify the omission of significant cultural voices in music education through pre-service music teacher preparation and, subsequently, in-service music teaching practice; however, much still needs to be done. Social justice, equitable access, and culturally-responsive pedagogy have implications for addressing issues of power in music education and music teacher preparation.

If our profession is to address these issues successfully, new approaches and new conversations are needed which challenge the paradigm of exclusivity in repertoire and pedagogy. Internationally, there are several examples of such approaches. One example involves connecting university students with missing voices via service learning for pre-service music educators. In the Manguang String Programme, music education students at the University of the Free State (UFS) in South Africa teach music lessons to children in historically-disadvantaged townships and rural schools. In those lessons, repertoire includes Black South African folk melodies and pedagogy features an aural learning approach, honoring the 
transmission authentic to the Black folk tradition, while fulfilling a compulsory service learning requirement at UFS (Cloete, 2006). Here the content and the mode of instruction are appropriate within a community where this music holds strong cultural value.

Another example of the effort to ensure that the musical culture of a people is preserved for the future through music education is the 'Music Recovery' project developed by clarinetist Ros Dunlop in collaboration with composer Martin Wesley-Smith. The project involves developing a music school in East Timor where part of the curriculum reflects the indigenous music of the island country. Additionally, there are plans to incorporate cross-cultural exchanges between Australian teachers and teachers of East Timor (Sydney Conservatorium of Music, 2009). The 'Music Recovery' project demonstrates how music education can serve as a means to protect and maintain the musical culture of a people, rather than diminishing or devaluing it.

Such new and exciting approaches in music education internationally suggest that equally innovative programs might be possible in the United States if a critical lens were focused on music teacher education. In a discussion of critical research in urban education and school reform, Benigno, Lynn, Mitchell, Park, and Williams (2007) argued for critical theory as a starting place for conversation that might lead to humanizing and empowering students in urban schools. In both ethnomusicology and historical musicology, critical inquiry into the power of sound has led to a reconsideration of music listening as potentially revisionist (Radano, 2005), an activity in which the ideals of a cultural construct are established, as opposed to being grounded in past reality. Oppressed originally through slavery, and later through segregation, African Americans had neither social nor academic power during the days of Appalachia's collected folk music, which may account for their omission in the idealized chronicling of that region's musical history. The high poverty rates in urban schools suggest that the attainment of economic and educational power are disproportionately challenging for people of color in the USA. The examination of power relationships and their influence on social circumstances are cornerstones of critical inquiry, which supports a social justice model for music teaching.

Where revisionist music education exists, historical facts are sometimes skewed and/or omitted due to an idealized collective memory, such as the exclusively Anglo-Appalachian heritage propagated by most 20th century historians and educators. To combat this bias, future music educators need to develop a critical consciousness while simultaneously developing pedagogy and identity as teachers. Also, critical consciousness is enhanced by an ethnographic study of one's own musical development (Campbell, 2002; Woodford, 2002). The pre-service teachers in Kindall-Smith's music education courses at the The University of Wisconsin-Milwaukee began this process with autobiographies, discussions, exam questions and reflective writing based on music education curriculum and assigned social justice readings. This approach addressed the 'gap' reported by students when they sought to negotiate the idealized realities of their musical past with the realities they uncovered about the power structures influencing music education (Kindall-Smith, 2008a). Kindall-Smith's students were able to fill in the gap because of course pedagogy and all pre-service music education students have the capacity to do the same. Ideally this transformation begins by 'involving the entire learning community . . . in discussions of . . . values for social justice' (Kindall-Smith, 2006), including admissions/audition procedures (Spearman, 2000), and continues by providing students with '21st century multi-musical experiences . . . suffused into every facet of the undergraduate music education curriculum' (Robinson, 2002, p. 234).

These approaches to teacher education address Paulo Freire's call for the development of critical educators who have a sufficient command of their specific subject matter to be able to teach elements of the traditional canon while simultaneously providing opportunities for students to engage critically the content of the canon based upon their own knowledge and lived experiences (Freire, 2000). Thus Freire's call, which is our call as well, requires two changes. First, a change in traditional conceptions of how 
factors that may serve as barriers to or supports for music learning within the dimensions of content, instruction, and context (as outlined in the conceptual model previously described) function within the framework of music education and music teacher preparation. Second, a change is needed that allows teachers and students to embrace a perspective where diverse musical voices may be worthy of expression and study, and accessible to all music students. As mentioned previously, the teacher and student are the primary dimensions of the conceptual model but each is affected by the other three dimensions, both singularly and in concert. Pre-service teachers' abilities to understand how race, ethnicity and culture impact both the process of music learning and teaching and the content comprising what is taught demands employment of a critical lens. As has been demonstrated, the development of dispositions toward social justice, culturally-responsive teaching and equitable access in music education can occur when pre-service teachers are dynamically engaged with culturally-diverse perspectives. Thus, once music teacher educators are committed to social justice through their own pedagogies and practices, the inclusion of culturally-diverse voices and perspectives in music education can become an established and expected curricular goal benefiting both learners and teachers.

\section{References}

Abril, C. R. (2006). Teaching music in urban landscapes: Three perspectives. In C. Frierson-Campbell (Ed.), Teaching music in the urban classroom (Vol. 1, pp. 75-95). Lanham, MD: Rowman \& Littlefield.

Benedict, C. (2006). Defining ourselves as other: Envisioning transformative possibilities. In C. FriersonCampbell (Ed.), Teaching music in the urban classroom. (Vol. 1, pp. 20-35). Blue Ridge Summit, PA: Rowman \& Littlefield.

Benigno, G., Lynn, M., Mitchell, C., Park, G., \& Williams, A. (2007). Race, class, and gender in urban education: Exploring the critical research on urban pedagogy and school reform. In J. L. Kincheloe, K. Hayes, K. Rose, \& P. Anderson (Eds.), Urban education: A comprehensive guide for educators, parents, and teachers (pp. 89-100) Lanham, MD: Rowman \& Littlefield.

Butler, A., Lind, V. R., \& McKoy, C. L. (2007). Equity and access in music education: Conceptualizing culture as barriers to and supports for music learning. Music Education Research, 9, 241-253.

Campbell, P. S. (2002). In study of expressive cultures. In B. Reimer (Ed.), World musics and music education: Facing the issues (pp. 239-258). Reston, VA: The National Association for Music Education.

Cochran-Smith, M. (2008). Teacher education: Where are we and where are we going? In M. Schmidt (Ed.), Collaborative action for change: Selected proceedings from the 2007 symposium on music teacher education (pp. 3-22). Lanham, MD: Rowman \& Littlefield.

Cloete, E. (2006). Broadening a horizon of expectations: A qualitative investigation of the Mangaung string programme. Journal of the Musical Arts in Africa, 3, 16-38.

Darling-Hammond, L., French, J., \& Garcia-Lopez, S. (2002). Learning to teach for social justice. New York: Teachers College Press.

Freire, P. (2000). Pedagogy of the oppressed (30th anniversary ed.). New York: Continuum.

Frierson-Campbell, C. (Ed.). (2006). Teaching music in the urban classroom (Vol. 1). Lanham, MD: Rowman \& Littlefield.

Gay, G. (2002). Preparing for culturally responsive teaching. Journal of Teacher Education, 53, 106-116.

Green, L. (2001). Music in society. In C. Philpott \& C. Plummeridge (Eds.), Issues in music education (pp. 47-60). London: Routledge-Falmer.

Hay, F. J. (2005) Black musicians in Appalachia: An introduction to Appalachian music. Black Music Research Journal, 23, 1-19.

Hawes, B. L., \& Jones, B. (1972). Step it down: Games, plays, songs \& stories from the Afro-American heritage. New York: Harper and Row.

Hollins, E. R., \& Guzman, M. T. (2005) Research on preparing teachers for diverse populations. In M. Cochran-Smith \& K. Zeichner (Eds.), Studying teacher education: The report of the AERA panel on research and teacher education (pp. 477-548). Washington, DC: American Educational Research Association.

Johnson, B. L. (2004). A sound education for all: Multicultural issues in music education. Educational Policy, 18, 116-141. 
Kincheloe, J., hayes, k., Rose, K., \& Anderson, P. (Eds.). (2007). Urban education: A comprehensive guide for educators, parents, and teachers. Lanham, MD: Rowman \& Littlefield.

Kindall-Smith, M. (2006). I plant my feet on higher ground: Music teacher education for urban schools. In C. Frierson-Campbell (Ed.), Teaching music in the urban classroom (Vol. 2, pp. 47-66). Lanham, MD: Rowman \& Littlefield.

Kindall-Smith, M. (2008a). A half-baked cake/inedible pudding in music teacher education. The National Journal of Urban Education \& Practice, 1, 281-291.

Kindall-Smith, M. (2008b). Teaching social justice IS touching lives. Session presented at the 61st MENC National Biennial In-Service Conference, April, Milwaukee, WI, USA.

Kindall-Smith, M., \& Mills, S. W. (2008). Missing Appalachian and urban voices in world music education. Proceedings from the 9th International Conference on Cultural Diversity in Music Education, March [CDROM]. Seattle, WA: University of Washington School of Music.

Kwami, R. M. (2001). Music in and for a pluralist society. In C. Philpott \& C. Plummeridge (Eds.), Issues in music education (pp. 142-155). London: Routledge-Falmer.

Lomax, A. (1960). The folk songs of North America. Garden City, NY: Doubleday.

Mills, S. (2007). Appalachian music fellowship final report. Available from Berea College Hutchins Library Special Collection and Archives. Berea, Kentucky.

Nieto, S., \& Bode, P. (2008). Affirming diversity: The sociopolitical context of multicultural education (5th ed.). Boston, MA: Pearson.

Radano, R. (2005). Lying up a nation. Chicago, IL: The University of Chicago Press.

Ritchie, J. (1997). Folk songs of the Southern Appalachians (2nd ed.). Lexington, KY: University Press of Kentucky.

Roberts, L. (2003). Leonard Roberts papers. Available from Berea College Hutchins Library Special Collections and Archives, Appalachian Music Collection. Berea, Kentucky.

Robinson, K. M. (2002). Teacher education for a new world of musics. In B. Reimer (Ed.), World musics and music education: Facing the issues (pp. 219-238). Reston, VA: Music Educators National Conference.

Robinson, K. M. (2006). White teacher, students of color: Culturally responsive pedagogy for elementary general music in communities of color. In C. Frierson-Campbell (Ed.), Teaching music in the urban classroom (Vol. 1, pp. 35-53). Lanham, MD: Rowman \& Littlefield.

Small, C. (1999). Musicking - The means of performing and listening: A lecture. Music Education Research, 1, 1-25.

Smith, J. (2006). The challenges of urban teaching: Young urban music educators at work. In C. FriersonCampbell (Ed.), Teaching music in the urban classroom (Vol. 1, pp. 57-74). Lanham, MD: Rowman \& Littlefield.

Spearman, C. E. (2000). How will societal and technological changes affect the teaching of music? In C. K. Madsen (Ed.), Vision 2020: The Housewright symposium on the future of music education (pp. 153-184). Reston, VA: The National Association for Music Education.

Spruce, G. (2001). Music assessment and the hegemony of musical heritage. In C. Philpott \& C. Plummeridge (Eds.), Issues in music education (pp. 118-130). London: Routledge-Falmer.

Suttles, J. (Producer), \& Hopkins, T. (Director). (2002). Three cultures of Appalachia [motion picture]. United States: Suttle Film \& Media.

Sydney Conservatorium of Music (2009). School's in for Ros [Press release]. Retrieved 13 August 2010 from http://www.usyd.edu.au/news/music/763.html?newsstoryid=3703

Toppo, G. (2003). The face of the American teacher white and female, while her students are ethnically diverse. USA Today, 2 July, 1D. Retrieved from Newspaper Source Plus database.

Tuckman, B. (1999). Conducting educational research (5th ed.). Fort Worth, TX: Wadsworth.

Villegas, M., \& Lucas, T. (2002). Educating culturally-responsive teachers. Albany, NY: State University of New York Press.

Wilson, S. H. (2006). Berea College: An illustrated history. Lexington, KY: University of Kentucky Press. Woodford, P. (2002). The social construction of music teacher identity in undergraduate music education majors. In R. Colwell \& C. Richardson (Eds.), The new handbook of research on music teaching and learning (p. 675-694). New York: Oxford University Press. 